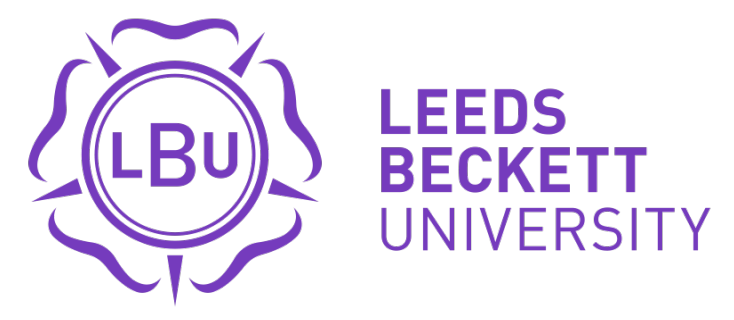

Citation:

Dean, A and Shubita, M and Claxton, J (2020) What type of learning journey do students value most? Understanding enduring factors from the NSS leading to responsible decision-making. Journal of Global Responsibility, 11 (4). pp. 347-362. ISSN 2041-2568 DOI: https://doi.org/10.1108/JGR-012020-0017

Link to Leeds Beckett Repository record:

https://eprints.leedsbeckett.ac.uk/id/eprint/6859/

Document Version:

Article (Accepted Version)

Creative Commons: Attribution-Noncommercial 4.0

This is an Accepted Manuscript of an article published by Emerald in Journal of Global Responsibility on 29th July 2020, available online: https://doi.org/10.1108/JGR-01-2020-0017

The aim of the Leeds Beckett Repository is to provide open access to our research, as required by funder policies and permitted by publishers and copyright law.

The Leeds Beckett repository holds a wide range of publications, each of which has been checked for copyright and the relevant embargo period has been applied by the Research Services team.

We operate on a standard take-down policy. If you are the author or publisher of an output and you would like it removed from the repository, please contact us and we will investigate on a case-by-case basis.

Each thesis in the repository has been cleared where necessary by the author for third party copyright. If you would like a thesis to be removed from the repository or believe there is an issue with copyright, please contact us on openaccess@leedsbeckett.ac.uk and we will investigate on a case-by-case basis. 


\title{
What type of learning journey do students value most? Understanding enduring factors from the NSS leading to responsible decision-making.
}

\author{
By:
}

\section{Aftab Dean ${ }^{1}$ \\ Moade Shubita ${ }^{1^{*}}$ \\ Julia Claxton ${ }^{1}$}

${ }^{1}$ Leeds Business School, Leeds Beckett University, Leeds. UK.

${ }^{*}$ Corrsponding Author: Email: m.f.shubita@leedsbeckett.ac.uk/ ORCID: 0000-0002-1465-9047

\begin{abstract}
Purpose: The purpose of this research is to support responsible decision-making in Higher Education (HE) settings by understanding what type of learning journey satisfies students most in their HE experience and what they want from the learning.
\end{abstract}

Design/methodology/approach: This paper analyses the key tool used to assess satisfaction factors for UK students, the National Student Survey (NSS). It adopts peculiar regression statistical tests to identify the NSS items that influence 'overall student satisfaction' by reviewing responses over 9 years from accountancy students at business schools located in England.

Findings: The findings of the study provide evidence that students are most satisfied with a learning journey where they are part of a course that is 'well organised and running smoothly', that provides 'intellectual stimulation', that helps in developing their ability to 'present themselves with confidence', and provides 'academic advice and support'. The findings of the paper show that students are not satisfied so much by utilitarian aspects of learning but rather those that relate to who they are and where they are in their learning journey, the level of intellectual stimulation they have experienced, the self-confidence they have developed and the supportive relationship they have developed with academics. A factor that did not relate highly was 'assessment and feedback' which has been the focus of much university resource. In working with these findings, the authors found the factors that impacted overall satisfaction the most all related to students wanting to develop personal responsibility. These findings shape the key principles of responsible design and management of HE programmes and influence strategic decision-making. 
Practical implications: Focussing on helping students experience the type of learning journey that develops the virtue of responsibility emergent from the analysis will not satisfy the student but will also have a knockon effect of improving NSS scores, university league table ranking and accreditation under the Teaching Excellence Framework. The improved reputation aspects would then feed back into increased student satisfaction (Dean and Gibbs, 2015). The findings will also help HE managers and leaders to evaluate their decisions through three lenses: responsibility, students' experience and students overall learning journey.

Originality/value: Much of the information published on the NSS have been predominantly descriptive and has resulted in decisions being made for students based on uninformed analysis of the survey's results. This study employs advanced statistical modelling to evidence the relationship between factors of the NSS and overall student satisfaction providing key information regarding students' importance to the type of learning journey they value and that this relates to a desire in wanting to develop responsibility. This study shows the link between factors of the NSS to provide useful lenses for HE managers and leaders to use in order to support responsible decision-making processes.

Keywords: learning journey, student valued learning, student responsibility, student satisfaction, HE decision-making, accounting education. 


\section{INTRODUCTION}

Universities are being called upon to improve the service quality to their fee-paying students. Metrics like the Teaching Excellence Framework (TEF), fifty percent of which is derived from the National Student Survey (NSS) results are used to grade a University. Student satisfaction scores are increasingly being adopted to compile university league tables in England (e.g. The Complete University Guide; Guardian University league table). However, even without pressure to perform better because of the assessments, responsible leaders have the desire to satisfy students, but they need quality data to do this. Responsible decision-making can only come about if leaders know exactly how student evaluation of their experience creates satisfaction grades. To be able to employ university funds responsibly there needs to be clear evidence of which aspects of the student experience affects their overall satisfaction and to what degree. The purpose of this research is to understand what type of learning journey satisfies students most in their Higher Education (HE) experience and what they want from the learning. A longitudinal analysis (from 2008 to 2016) of the NSS results of students was used to provide a understanding of the enduring key factors related to overall satisfaction.

\section{Responsible Decision-Making}

A decision is a "choice made between two or more alternatives" (Sugumaran \& DeGroote, 2011, p2-3) and Grunig \& Kuhn $(2005,7-8)$ suggest there are 5 ways to make a decision: intuition, adhering to routine procedures known to the decision-maker, adopting what the experts say without questioning it, choosing an alternative randomly or using information. The method of using information is the context of this paper and the assumption that the better the quality of information the more potential there is for a better decision. Decisions can only be effective decisions if they are based on valid data and validity comes through interpretation (Cronbach 1988). University leaders are responsible to the taxpayer for the public funds they use and to the student for the student payments they use. Whilst it is impossible to make responsible decisions without quality data, it is accepted that providing accurate data does not automatically mean it will be acted on responsibly. However, it is the best start to the process.

\section{Perceived Service Quality - Satisfaction:}

It is generally accepted that when students complete the NSS they are providing their assessment of their 'perceived' service quality. They are not assessing the service quality of the academic education that the 
institution is actually providing but rather, what is 'perceived' as being provided. "The perceived quality of service is a cognitive process of evaluating quality, which means that assessing service quality is a psychological result of perception, learning, reasoning and comprehensive on the service attributes" (Sultan \& Wong 2012 cited in Eugenia et al 2018, p169). Service quality assessment is based on the students' personal perceptions and expectations (Cameron et al 2010). It can be argued that students are not able to assess 'actual' quality because they do not see the whole picture of the purpose of academic learning. However, the NSS is the tool of measurement that is widely used to measure student satisfaction. We purport that responsible decision-making requires a full understanding of how each factor of the NSS contributes to its overall score of satisfaction and, taking into account it is a 'perceived' view, to then, using other expertise, balance this with the responsibility of furthering the purpose of universities in developing learning and creating knowledge, some elements of which may not be scored on at all. Responsible education requires the best information to be available to enable leaders to provide a careful balance of what a student wants and feel they are paying for as well as what a university's mission is. Using a satisfaction questionnaire for judging and awarding universities can come at the detriment of the welfare of the academic community including the students but it can also show what the students are valuing. There is a growing body of support in the literature for the view of students as customers (Sines and Duckworth, 1994; Salter and Tapper, 2002; Olssen and Peter, 2005; Furedi, 2011) rather than learners (Leathwood and O'Connell, 2003). Most of this is a response to universities competing for student income and the increased role of marketing which has a philosophy of satisfying paying customers not meeting learners' needs. Viewing a student as a consumer redefines the role of the academic who is increasingly seen as a product provider rather than an educator (Nordensvard, 2011). While there is a number of academics who support the argument that students should be treated as customers $(\mathrm{Ng}$ and Forbes, 2009; Schee, 2011), there is growing opposition to this (see Bay and Daniel, 2001; Clayson and Haley, 2005; Canic and McCarthy, 2000; Maguad, 2007). One such argument against the student-as-customer paradigm, put forward by Franz (1988), is that viewing the student as a customer may subvert academic rigour to student desires and could potentially lead to grade inflation. Other authors advocate concern over the abdication of reduced student responsibility (Hassel and Lourey, 2005). Robinson and Sykes (2014, p.37) argue that it would be more appropriate to view students as learners rather than consumers when evaluating their higher 
education experience. However, are students best placed to assess what helps them to become accomplished learners? Other researchers have put forward the role of students as co-creators or co-producers in their learning experience (Bitner et al., 1997; Kotze and du Plessis, 2003; Ng and Forbes, 2009). This view requires students to co-produce which can be a challenge, given the variation of attendance policies and expectations of engagement among many Higher Education Institutions (HEIs). This paper purports that students, rather like patients, are a category of their own and have unique needs that cannot be captured by viewing them as only customers, only consumers or only learners. They are unique. They are students. They do know what they want.

\section{National Student Survey (NSS)}

An assessment of 'overall student satisfaction' of the learning environment at a HEI can highlight areas of strength and identify areas for improvement (Eom et al, 2006; Kember and Ginns, 2012; Zerihun et al, 2012). This is supported by Harvey (2003) who advocates that seeking feedback from students on their learning experience has two main functions. These are:

1. Generating internal information to guide improvement; and

2. Generating external information for potential students and other stakeholders, including accountability and compliance requirements.

In the 1990s, feedback from students on their HE experience was a rarity. The Quality Assurance Agency had a significant drive to elicit student views through a survey instrument. Their aspiration was achieved in 2005 when the Higher Education Funding Council for England introduced the NSS as the measurement tool to assess student experience at University.

The NSS elicits the views of final-year undergraduate students on a number of educational themes, to determine an overall satisfaction rating in order to help prospective students compare courses at HEIs (Williams and Cappuccini-Ansfield, 2007). 
The United Kingdom is unique in administering its students' evaluation of teaching in that the survey takes place while students are still in their final year of study as opposed to administering the survey at the end or several months after completion of studies, where reflection on the whole experience might be more insightful. The decision to administer the survey while students are still in their final year of study was partly influenced by the decision to ensure that the view of international students would be captured. Since its introduction the response rate from final year undergraduates to the NSS has steadily grown, and in 2016 the response rate reached a record high of $72 \%$.

A number of items, and pedagogical themes, relating to the HE student experience were initially included in the NSS. During the pilot phase, however, the NSS instrument was reduced down to six core themes, namely: Teaching, Assessment and Feedback; Academic Support; Organisation and Management; Learning Resources; and Personal Development. Clearly, the compromise to keep the NSS questionnaire to a manageable length could not capture all the student experiences and factors that influence student satisfaction. Nevertheless, the instrument does provide important insight into the learning experience at HEIs.

As well as the moral element of serving students well, universities can reap major financial and reputational benefits from improving the learning environment for students. The NSS is promoted as a student experience survey that can help universities identify areas for improvement to ensure they are meeting student expectations. There are benefits from engaging with the survey instrument despite it coming under criticism. One concern is that maintaining constantly improved performance to meet increased levels of student satisfaction may place undue physical and emotional demands on staff (Hey, 2011). 


\section{Robustness of the NSS instrument}

Careful use of the NSS and understanding its limitations are important. The NSS has provoked criticism in terms of the survey instrument (Ramsden, 2004, Shepherd, 2006), interpretation of results (Prosser, 2005), the instrument's subjectivity (Marsh et al., 2002), and claims that its focus is on courses and not tutors (Cheng and Marsh, 2010). Surridge (2009, p.30) warns of the danger of misinterpreting the NSS results. For instance, an institute may achieve consistently higher NSS student satisfaction scores each year but these improvements may actually be lower than the average improvement in the sector. Thus, the results can be misleading if they are not compared with the sector average ratings for each NSS theme. Other concerns about the NSS are highlighted by Sabri (2010) who critizes the NSS as diminishing academic integrity by focusing on student experience which views academics as mere providers and students as customers. Other researchers, Leckey and Neill (2001), argue that students are not trained assessors and good performance is seldom recognised. Consequently, Fielding et al. (2010), advocate that the information from the NSS survey should be used contextually and not over simplistically.

Though the NSS data provide a rich repository of information on the student experience which allows institutes to benchmark their performance, both Surridge (2009, p.6) and Marsh and Cheng (2008) suggest the need for caution when making comparisons either between different subject groups within an institution or within a subject group across institutions. There is a number of variables that could affect the student experience, such as the reputation of the institute, socio-economic background of respondents, ethnicity, institute resources, cohort size and composition, etc.

Despite these criticisms, the NSSis still viewed as vital to the quality enhancement in UK higher education (Beltyukova and Fox, 2002; Williams and Cappuccini-Ansfield, 2007) and after 15 years it is here to stay.

\section{Research Aim}

Therefore, this study, accepting the limitations of the NSS, seeks to identify, through statistical proof, that what students' value can be found through hierarchical order of the NSS items. Awareness of this hierarchy and the relationship between assessment items and overall satisfaction is key to finding out what factors students care about most and thereby what factors HE leaders can focus on to support students and to make responsible decisions for their portfolios. 


\section{METHODOLOGY}

Participants for the Study

The UK university sector is dominated by three categories of Universities. Firstly, the Russell Group, the equivalent of America's Ivy League universities, which represents the leading research Universities in England. They have a long historical origin of establishment and account for two thirds of all research publications in the University sector (https://russellgroup.ac.uk/about/our-universities/). Secondly, the Pre 92 Universities, established after the Second World War, in the 1960s, to cater to the rising demand for Higher Education. This period saw the number of England's universities double from 22 to 45 . Thirdly, former polytechnics and technical institutes whose original focus was on applied education for vocational and professional work. This third group were given university status through the Further and Higher Education Act 1992; hence they are referred to as Post 92 Universities. Consequently, these three groups of universities, used in this research, represent the evolution of the university sector in England and the hierarchy of entry requirements, in terms of student grades in exams, to qualify for entry. Using all three university groups in this research helps to identify the patterns of NSS ratings across all students.

Accountancy students were selected as the participants. This was for two reasons: firstly, accountancy courses are very popular within business schools, and the students make a large portion of the business school body and all require professional accreditation to be eligible to practice in this field and therefore work to the same standards across all university groupings. Secondly, accounting as a profession provides key information to industry and society leaders enabling them to make decisions. The theme of accuracy of information enabling responsible decision- making resonated with the purpose of this study and the interests of the authors so choosing accountancy students supported this.

To ensure that the analyses generated robust and rigorous findings, a framework was adopted to provide a consistent format in selecting universities that offered accountancy courses. This involved accepting the HEA criteria and selecting only universities that achieved a response rate of 23 or more for their course. 
Introduced in 2005, the NSS had become, in as little as three years, an established survey in terms of university participation and student response rates, making 2008 an appropriate start date for this analysis. 2016 was selected as the final date of this study.

\section{Data Analysis and Findings}

As the data on the NSS is ordinal, this research adopted ordinal regression analysis to determine which NSS item had the most significant impact on 'overall student satisfaction'. Much of the information published on the findings of the NSS has been predominantly descriptive. Leading researchers such as Gibbs (2010, p.5), however, has advocated the use of multivariate analysis to highlight the complexity and interaction of factors that influence educational performance. Gibbs argues that this will permit researchers to draw valid conclusions on the student experience. Therefore, the authors of this paper have chosen to adopt the most appropriate advanced statistical modelling techniques to provide valid insight into what impacts student satisfaction of accountancy students.

\section{Descriptive Analysis}

The results in Figure 1 reveal that the number of students completing the NSS survey from 2008 to 2016 increased at Russell Group Universities and decreased at Pre-92 Universities while remaining fairly consistent at Post-92 Universities.

\section{Figure 1 here}

Figure 2 shows the scores over time of dfferent themes in the survey. The overall trend for most of the NSS themes in HE has been quite positive 2011 to 2016. An area that has annually received a poor rating by students from 2008 to 2016 is Assessment and Feedback (see lowest line on figure 2). There is growing consensus on the key findings from the NSS data, which has resulted in discussions centred on issues related to Assessment and Feedback (Surridge, 2007, 2009). This is partly attributed to the plethora of descriptive analysis of the NSS results that are being communicated to course leaders and discussed by senior managers based on published NSS reports. This research confirms that the NSS items consistently achieving the lowest scores are in the Assessment and Feedback category.

Figure 2 here. 
While all universities have made improvements to their Assessment and Feedback (especially Russell Group Universities) and Academic Support ratings (see Figure 3), Post-92 universities have achieved lower ratings for their Teaching and Personal Development (see Figure 3). However, Post-92 Universities have made major improvements in their ratings for Organisation and Management 2011 to 2016.

\section{Figure 3 here}

Figure 4 reviews the improvement in student rating by university mission group. Russell Group universities have achieved the highest improvement in rating scores in the areas of Assessment and Feedback, Personal Development, and Overall Satisfaction of their courses (see Figure 4), though starting from a lower base.

\section{Figure 4 here.}

While descriptive analysis offers insights into areas of strength and improvement (Zerihun et al, 2012), the results can be misleading if multivariate analysis is not undertaken to reveal the true student priorities.

\section{Analysis Across Two Time Periods}

To undertake comparative analysis of the longitudinal time period the timeframe was segmented into two time periods. Time period 1 included NSS data from 2008 to 2011, and Time period 2 included NSS data from 2012 to 2016 . The grouping of the two time periods was facilitated by the distinct patterns that emerged from the analysis, namely:

1. Time period 1 When the NSS was first introduced there were a limited number of universities who actively promoted the survey to their students. Consequently, the response rates for the first time period were fairly low and this resulted in many universities being excluded from the analysis as they failed to reach the minimum threashhold of responses to be included in publication of NSS results. Thus, for time period 1 only 30 universities were identified who met the minimum threshold of student completion of the NSS to be included in this research project.

Time period 2 there were 76 universities that qualified for analysis based on the response rates achieved by universities from their accountancy students.

2. Descriptive analysis of the two-time periods showed varied ratings for the three groups of Universities (Russell Group, Pre-92 and Post-92). The comparative differences between the two time periods are highlighted in Figure 4 which reveals that Russell Group universites achieved a higher rating for 
Assessement and Feedback in Time periods 2, while Pre 92 universities achieved a much higher rating for their learning resources, in relation to other univerity groups, in time period 2. Finally, Post 92 universities achieved the most improvement for their organisation and management of courses in time period 2 in relation to the other university groups.

Time period 1 (2008 to 2011) comprised 30 English universities (4 Russell Group, 6 Pre-92 and 24 Post-92) and Time period 2 (2012 to 2016) comprised 76 universities (12 Russell Group, 19 Pre-92 and 46 Post-92).

Relationships between NSS measures Initially to determine whether any NSS items (Q1 to Q21) was associated with Q22 (overall satisfaction), Spearman correlation analysis was undertaken. The Spearman Rank-Order correlation coefficient is a measure of association between two variables which requires that both variables be measured in at least an ordinal scale (Siegal and Castellan, 1988, p. 235).

Table 1 shows the NSS items that are most correlated with Q22 (overall satisfaction). The themes most highly correlated with 'overall student satisfaction' for both time periods were: Organisation and Management; Teaching; Academic Support; and Personal Development. What is most notable from the correlation results is that Assessment and Feedback variables are not highly correlated with Q22 (overall satisfaction) and are thus absent from the table.

\section{Table 1 here.}

While correlation results provide an understanding into the association between two NSS items and 'overall student satisfaction', further advanced statistical tests are required to determine which NSS items significantly influence 'overall student satisfaction'. The most appropriate test to determine this is Ordinal Regression, since the measurement scales used in the NSS instrument are ordinal and the ordinal regression results can provide a more powerful insight into computed statistical influence of each NSS item on 'overall student satisfaction'.

Ordinal regression allows the analyst to identify the significant explanatory variables (in this case NSS items Q1 to Q21) that influence the outcome variable (in this case Overall Student Satisfaction - Q22). This is preferable to multilinear regression, which is limited by the criteria of homoscedasticity and multinomial regression and by its inability to consider the ordering of the categories for the dependent variable. Thus, the 
ordinal regression model becomes a preferable modelling tool as it does not make the assumptions of normality and constant variance (Chen and Hughes, 2004, p.2).

The initial model-fit results revealed a significant chi-squared value for model fit for both time periods 1 and 2. The model-fit results were then compared with the pseudo R-squared results. Pseudo R-squared measures the success of the model in explaining the variation in the data: the larger the R-squared value, the better the model fitting (Chen and Hughes, 2004, p.7). The two tests that indicate the pseudo R-squared value for ordinal regression are Cox and Snell and Nagelkerke tests. The Nagelkerke's result is preferred as it has a range of 0 to 1 which makes it analogous to the traditional $\mathrm{R}$ squared value. Statistically, a regression model with a Nagelkerke R-squared value above 0.5 confirms a very good adjustment of the model to the observed values (Gerpott \& Mahmudova, 2006, p.4)For both time periods (1 and 2) the Nagelkerke result is greater than 0.6 ( 0.60 for time period 1 and 0.68 for time period 2), confirming a good-fit model.

The computed results for ordinal regression tests are presented in Table 2. The results for both time period 1 and time period 2 have been placed side-by-side to enable the reader to compare visually figures over the two time periods.

Table 2 here.

The results in Table 2 reveal that there are four key NSS items that have the most influence on Q22 'overall satisfaction', in order of importance these are: Q15 related to the course being well organised and running smoothly; Q19 related to presenting oneself with confidence; Q4 related to teaching; and Q10 related to academic support; Out of these, in both time periods (1 and 2), Q15 ("The course is well organised and is running smoothly") is consistently rated as the most important NSS item that influences overall student satisfaction.

So in summary the themes that have the most impact on 'overall student satisfaction' for both time periods, in order of importance, were shown to be:

- The course is well organised and is running smoothly

- the course has helped me present myself with confidence 
- the course is intellectually stimulating

- I have received sufficient academic advice and support

And the factor shown not to be so important:

- Feedback and Assessment

\section{DISCUSSION}

Looking at the four most important factors relating to student satisfaction over a 9-year period; together they express the type of learning journey the students most value. The journey speaks of the importance of personal growth and philosophical challenge rather than achieving surface level learning. It speaks of relationship and trust with academics. This paper will now consider each of the key elements in turn.

The course is well organised and is running smoothly. Students saying they are satisfied because the course is well organised and running smoothly implies they want to know where they are in their learning journey, what they are expected to be doing each week, what is happening to them next in their journey and how they can prepare themselves for this. By saying an organised and smoothly running course gives them satisfaction they are saying they value being organised themselves. It is impossible to know exactly what provides a student with the perception a course or module is organised without specific qualitative research but from informal conversations with students they consider such things as: clear week by week module learning materials accessible $24 / 7$ so that they can see the way ahead to organise their workload, the view ahead to get their heads around what is coming up, to be able to catch up by easily identifying the work they missed on specific dates, to have clear assessments with the same instructions/valuing given by all tutors with no variance for the same piece of work, assessment deadlines clear for whole year ahead so they can plan life events, an approachable course leader and relevant information easily available not hidden in long documents full of university processes.

The course has helped me present myself with confidence. When a student is satisfied because the course has helped them to present themselves with confidence this talks about personal growth and development. Students are identifying that confidence is an important skill for their future lives. Presenting oneself with 
confidence is key to successful job interviews and developing new relationships. Presenting one's viewpoints to others speaks of social engagement and this relates to being able to be accountable to others which is part of being responsible. A student valuing self-confidence and being able to identify when it has grown is a student values self-awareness. Autonomy is the desire to be self-directed (Pink 2009) and this requires personal developing in terms of speaking up and standing ground, all part of presenting with confidence.

The course is intellectually stimulating. When a student is satisfied because they are intellectually stimulated they are valuing the stimulation of mental habits, improvement to mental functioning and developing critical thinking skills. Critical thinking is evaluating a situation or coming to a judgement, incorporating rationality creativity and reflection (Dowson, 2015, p78). Critical thinking is self-directed, self-disciplined, selfmonitored, and self-corrective thinking (The foundation for Critical Thinking, 2020) It is about a student being responsible for their own ideas which Pink (2009) terms as mastery. Mastery is one of his three key elements for motivation along with autonomy and purpose; purpose being seen in the organised course and autonomy being seen in presenting with confidence being able to make desires clear to others. Mastery is the desire to keep improving at what is important (Pink 2009). Students who are satisfied by intellectual stimulation are wanting to improve their critical thinking skills and therefore are wanting to develop their responsibility for their thinking. Research by Thomas and Galambos (2004, p.263) identified teaching, of which we argue critical thinking is key, as possibly having the greatest effect on student satisfaction, as it is the principal product of higher education. The importance of the teaching abilities of staff is also supported by empirical evidence from the research by Douglas et al. (2006, p.263), whose findings indicated that services associated with the university's core provision (i.e., the lecture) are ranked by students as being highly important among the university's service provisions. Douglas et al., $(2006,264)$ advocate that the quality of teaching and learning will ultimately cause satisfaction or dissatisfaction for the students. So intellectual stimulation is about developing critical agency, questioning reality, being autonomous, having a subjective will to know, and needing information in order to be able to criticize (Rebughini, 2018). These all signify the development of responsibility in students. 
I have received sufficient academic advice and support. When a student is satisfied because they are receiving academic advice and support this relates to building an academic relationship and it speaks of trust. The intellectual stimulation described above comes from academic tutors using their knowledge and experience as well as their relational skills to help students to develop their critical thinking. Students want relationship and this is part of responsibility (Robinson and Dowson, 2011). In gaining academic advice and academic support, students have to give an account of their work and to reflect on their thinking, their practice, cope with criticism and alter their practice accordingly. This relates to integrity which in turn relates to responsibility (Robinson and Dowson, 2011). So we see that the type of journey that the student is preferring is one where elements of responsibility are valued.

Assessment and Feedback: There has been an unhealthy neurosis regarding the NSS results of Assessment and Feedback, which have been consistently rated the lowest since the introduction of the NSS. Whilst responsible leaders will want to ensure students are well supported and that they are provided with feedback on their work, the result from this analysis does not support spending time and resource on this theme in particular. Most tutors have experienced spending hours writing feedback for students only to have it uncollected. The superficial descriptive analysis of the NSS results has thwarted higher education from making bold initiatives in pedagogical experimentation, or initiatives that might have stimulated critical thinking and independent study and thus helped to develop sustainable skills that future employers would value from students. Much resource has been spent on developing repetitive formative assessment providing students with copious feedback and higher workloads with current managerial practices increasing stress levels in higher education (Villeneuve-Smith et al., 2008; Court and Kinman, 2009). The weak connection found between this factor and overall satisfaction implies that students are more interested in the intellectual, relational and development aspects of their learning journey than the utilitarian aspects.

For university managers, the findings provide evidence on how resources may be strategically employed to ensure they effectively support students in their quest to develop responsibility. Current management practices adopted in higher education are resulting in a new class of managers who are increasingly concerned with superficial and myopic views of student satisfaction. All too often rigorous quality assurance processes are 
implemented without taking into due consideration the nature of the development of student responsibility. This appropriate analysis of the NSS results over the 9 year period has shown that students value a learning journey where they are developing responsibility in terms of their critical thinking skills, their autonomy, their reflective skills, their relational skills, their ability to judge their own thinking and to take onboard criticism, their interpersonal skills, their personal development and their desire to be organised. Other researchers (Douglas et al. 2006; Gruber, et al. 2010; Dean and Gibbs, 2015) have developed their own instruments to capture data on a broader student experience. Results by Dean and Gibbs $(2015, \mathrm{p} .14)$ point to the growing importance of a university's reputation, social balance during studying and the equity of tutors' treatment of students as factors. Looking at how the four factors found here relate to reputation, social balance and equity would make another interesting study.

\section{CONCLUSION}

The study has provided statistical evidence that there has been minimal change over the last decade in the key factors that result in significantly influencing 'overall student satisfaction', these being: 'the course is well organised and is running smoothly'; 'the course has helped me present myself with confidence'; 'the course is intellectually stimulating' and 'I have received sufficient academic advice and support'.

This research also dispels the popular view that focusing on improving assessment and feedback ratings will result in improved 'overall student satisfaction' scores as this factor does not impact greatly on overall student satisfaction. The results from this research provide valuable insights to HE leaders and managers confirming that they should not just treat the students as customers, they should treat them as active participants of a dynamic learning journey where they embark on a journey involving responsible learning and responsibility. Hey (2011) expresses concern that constantly trying to improve performance level on the NSS places undue physical and emotional demands on staff. This research shows that this is not necessary and by focussing on what academics prefer to focus on, the development of students as responsible learners, NSS scores should increase at the same time. There is no need to have one at the expense of the other. Further, qualitative, research on how these four factors relate to student responsibility would be a next step. 


\section{References}

Bay, D., and H. Daniel. 2001. The Student Is Not the Customer- An Alternative Perspective. Journal of Marketing for Higher Education (Vol 11, No. 1) 1-19.

Beltyukova, S., and C. Fox. 2002. Student Satisfaction as a Measure of Student Development: Towards a Universal Metric. Journal of College Student Development (Vol 43, No 2) 161-172.

Bitner, M. J., W. T. Faranda, A. R. Hubbert, and V. A. Zeithaml. 1997. Customer contributions and roles in service delivery. International Journal of Service Industry Management (Vol 8, No. 3) 193-205.

Canic, M., and P. McCarthy. 2000. Service quality and higher education do mix: A case study exploring the service environment at Indiana University Southeast. Quality Progress (Vol. 33, No. 9) 41-46.

Chen, C.K., and J. Hughes. 2004. Using Ordinal Regression Model to Analyze Student Satisfaction Questionnaires. Association for Institutional Research (Vol. 1) 1-13.

Cheng, J., and H. Marsh. 2010. National Student Survey: are differences between universities and courses reliable and meaningful? Oxford Review of Education (Vol. 36, No 6) 693-712.

Chronbach, I,J.,1988. Five perspectives on validity argument in H. Wainer \& H Braun (Eds) Test Validity (pp3-17), Hillsdale NJ: Lawrence Erlbaum

Clayson, D., and D. Haley. 2005. Marketing models in education: students as customers, products, or partners. Marketing Education Review (Vol. 15, No. 1) 1-10.

Court, S., and G. Kinman. 2009. Tackling stress in further education. London: UCU.

Dean, A., and P. Gibbs. 2015. Student Satisfaction or Happiness? A Preliminary Rethink of What Is Important in the Student Experience. Quality Assurance in Education: An International Perspective (Vol. 23, No. 1) 5-19.

Douglas, J., A. Douglas, and B. Barnes. 2006. Measuring Student Satisfaction at a UK University. Quality Assurance in Education: An International Perspective (Vol. 14, No. 3) 251-267.

Dowson, P., 2015. Personal and Professional Development for business students. Sage.

Eom, S., H. Wen, and N. Ashill. 2006. The Determinants of Students' Perceived Learning Outcomes and Satisfaction in University Online Education: An Empirical Investigation. Decision Sciences Journal of Innovative Education (Vol. 4, No. 2) 215-235.

Fielding, A., P. Dunleavy, and A. Langan. 2010. Interpreting Context to the UK's National Student (Satisfaction) Survey Data for Science Subjects. Journal of Further and Higher Education (Vol 34, No. 3 ) 347-368.

Franz, R. 1998. Whatever you do, don't treat your students like customers! Journal of Management Education (Vol. 22, No. 1) 63-69.

Furedi, F. 2011. Introduction to the marketisation of higher education and student as consumer. The Marketisation of Higher Education and the Student as Consumer, edited by Mike Molesworth, Richard Scullion and Elizabeth Nixon, 1-7. Oxford: Routledge.

Gibbs, G. 2010. Dimensions of Quality. The Higher Education Academy https://www.heacademy.ac.uk/knowledge-hub/dimensions-quality. 
Gruber, T., S. Fuß, R. Voss, and M. Gläser-Zikuda. 2010. Examining student satisfaction with higher education services: Using a new measurement. International Journal of Public Sector Management (Vol. 23, No. 2) 105-123.

Harvey, L. 2003. Student feedback [1]. Quality in Higher Education (Vol. 9, No. 1) 3-20.

Hassel, H., and J. Lourey. 2005. The Dea(r)th of Student Responsibility, College Teaching (Vol. 53, No. 11) $2-13$.

Hey, V. 2011. Affective asymmetries: academics, austerity and the mis/recognition of emotion. Contemporary Social Science (Vol. 6, No. 2) 207-222.

Kember, D, and P. Ginns. 2012. Evaluating teaching and learning: A practical handbook for colleges, universities and the scholarship of teaching. Abing-don, Oxfordshire: Routledge.

Kotze, T., and P. Plessis. 2003. Students as "co-producers" of education: a proposed model of student socialisation and participation at tertiary institutions. Quality Assurance in Education: An International Perspective (Vol. 11, No. 4) 186-201.

Leathwood, C., and P. O'Connell. 2003. It's a struggle: the construction of the 'new student' in higher education. Journal of Education Policy (Vol. 18, No. 6) 597-615.

Leckey, J., and N. Neill. 2001. Quantifying Quality: the importance of student feedback. Quality in Higher Education (Vol. 7, No. 1) 21-38.

Maguad, B. 2007. Identifying the Needs of Customers in Higher Education. Education (Vol. 12, No. 3) $332-$ 343.

Marsh, H., and J. Cheng. 2008. National Student Survey of Teaching in UK Universities: Dimensionality, Multilevel Structure and Differentiation at the Level of University and Discipline: Preliminary Results. Higher Education Academy. York.

Marsh, H., K. Rowe, and A. Martin. 2002. PhD Students' Evaluations of Research Supervision. Journal of Higher Education (Vol. 73, No. 3) 313-348.

$\mathrm{Ng}$, I., and J. Forbes. Education as Service: The Understanding of University Experience through the Service Logic. Journal of Marketing for Higher Education (Vol. 19, No. 1) 38-64.

Nordensvard, J. 2011. The consumer metaphor versus the citizen metaphor: different sets of roles for students. The Marketisation of Higher Education and the Student as Consumer, edited by Mike Molesworth, Richard Scullion and Elizabeth Nixon, Chapter 13: 157-169. Oxford: Routledge.

Olssen, M., and M. Peters. 2005. Neoliberalism, Higher Education and the Knowledge Economy: From the Free Market to Knowledge Capitalism. Journal of Education Policy (Vol. 20, No. 3) 313-345.

Pink, D.H. 2009. The surprising truth about what motivates us. Riverhead Books, New York.

Prosser, M. 2005. Why we shouldn't use student evaluations of teaching as satisfaction ratings: Interpreting the results of student evaluations. The Higher Education Academy. York.

Ramsden, P. 2004. The evidence is there so let's make use of it. Times Higher Education Supplement, 1 October.

Rebughini, P. 2018. Critical Agency and the future of critique. Current Sociology (Vol. 66, No. 1) 3-19. 
Robinson, L., and A. Sykes. 2014. Listening to Students' Views on NSS Data for Quality Enhancement. Health \& Social Care Education (Vol. 3, No. 1) 35-40.

Robinson, S., and P. Dowson, 2011. Responsibility and integrity in the curriculum. Journal of Global Responsibility (Vol. 2, No. 2) 253-268

Sabri, D. 2010. Absence of the Academic from Higher Education Policy. Journal of Education Policy (Vol. 25, No. 2) 191-205.

Salter, B., and T. Tapper. 2002. The External Pressures on the Internal Governance of Universities. Higher Education Quarterly (Vol. 56, No. 3) 245-256.

Schee, B. 2011. Students as consumers: Programming for brand loyalty. Services Marketing Quarterly (Vol. 32, No. 1) 32- 43.

Shepherd, J. 2006. Student threat to boycott survey. Times Higher Education Supplement, 27 January.

Siegal, S., and J. Castellan. 1988. Nonparametric statistics for the behavioural sciences. $2^{\text {nd }}$ Ed. McGrawHill: London, UK.

Sines, R., and E. Duckworth. 1994. Customer service in higher education. Journal of Marketing for Higher Education (Vol. 5, No. 2) 1-15.

Sugumaran, R., \& J. DeGroote.,2011, Spatial decision support systems: principles and practices, Taylor \& Francis.

Sultan, P., \& Wong, H. Y. (2012). Service quality in a higher education context: an integrated model. Asia Pacific Journal of Marketing and Logistics, 24(5), 755-784 cited in Eugenia Pedro 1 Luis Mendes Luís

Lourenço (2018), Perceived Service Quality and Students' Satisfaction in Higher Education: the influence of teaching methods, International Journal for Quality Research 12(1) 165-192 ISSN 1800-6450

Surridge, P. 2007. The National Student Survey 2006: Report to Higher Education Funding Council for England.

Surridge, P. 2009. The National Student Survey three years on: what have we learned? Higher Education Academy.

The foundation for Critical Thinking, url cct@criticalthinking.ord, accessed on 28/5/20.

Villeneuve-Smith, F., S. Munoz, and E. McKenzie. 2008. FE Colleges: The Frontline under Pressure? London: The Learning and Skills Network.

Watson, P., 2010, The German Genius: Europe's Third Renaissance, the second scientific revolution and the twentieth century, London, Simon and Schuster

Williams, J., and G. Cappuccini-Ansfield. 2007. Fitness for Purpose? National and Institutional Approaches to Publicising the Student Voice. Quality in Higher Education (Vol. 13, No. 2) 159-172.

Zerihun, Z., J. Beishuizen, and W. Os. 2012. Student Learning Experience as Indicator of Teaching Quality. Educational Assessment, Evaluation and Accountability (Vol. 24, No. 2) 99-111. 


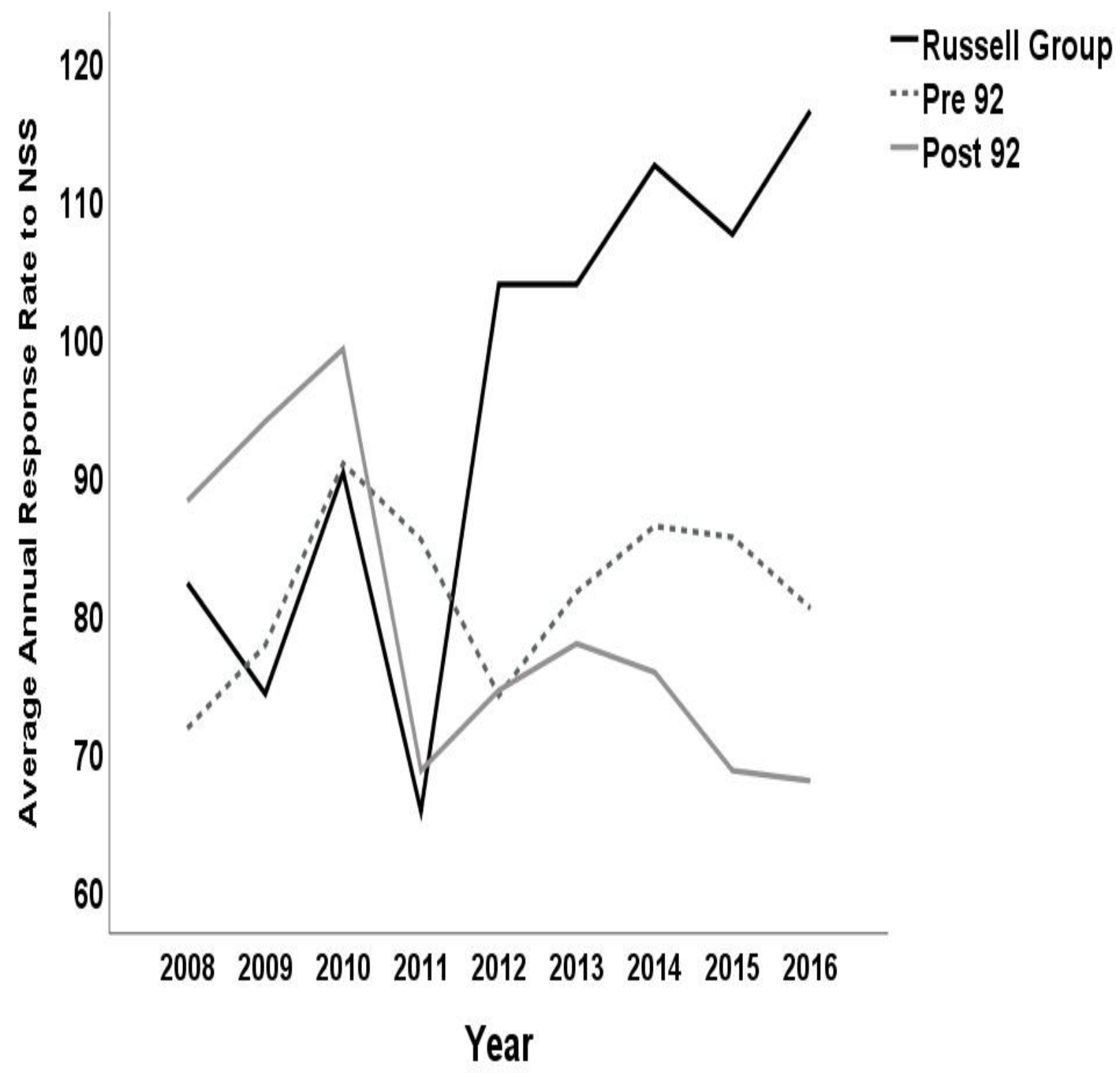

Figure 1: Student Response Rate to the NSS from 2008 to 2016, by mission group. 


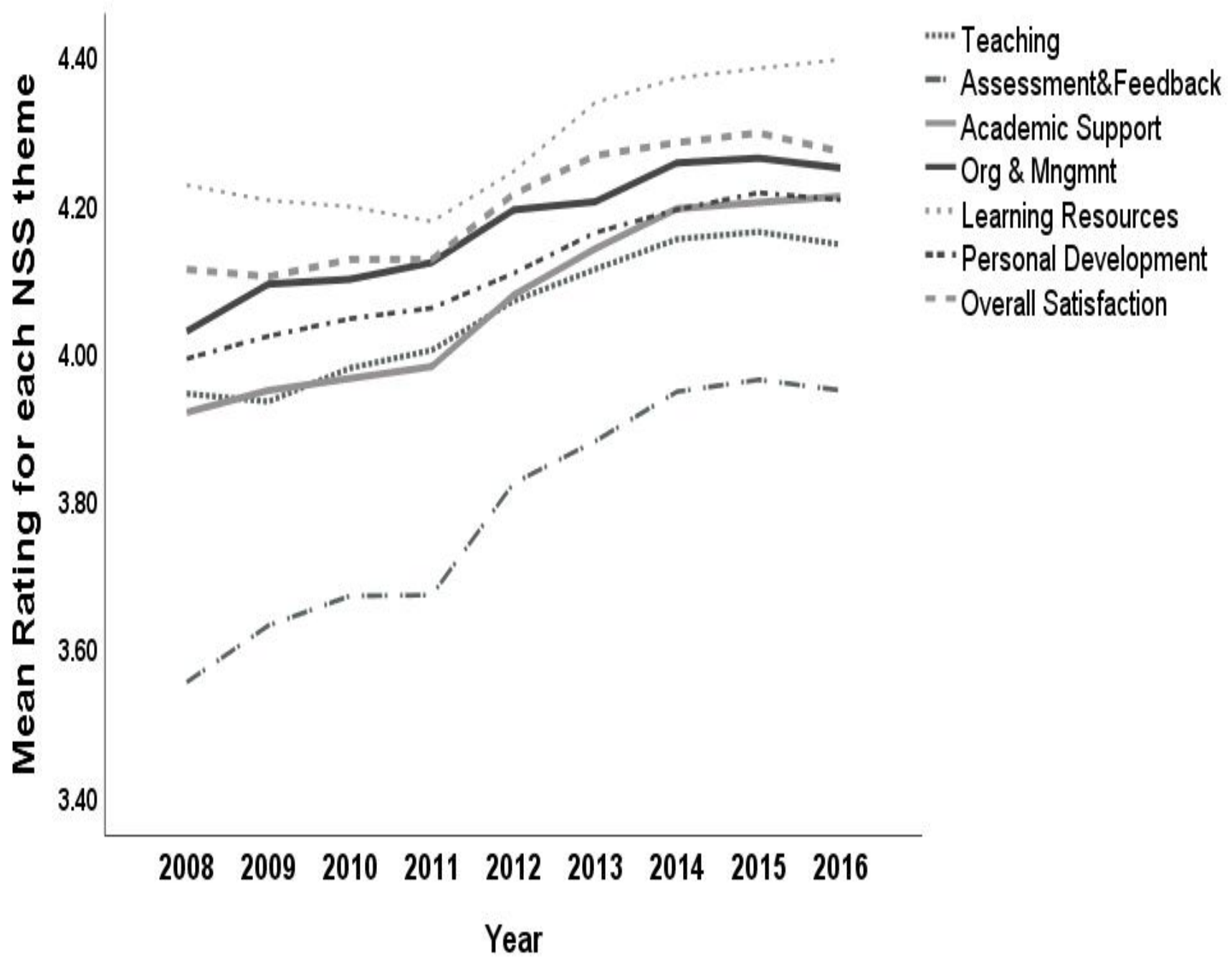

Figure 2: Overall Rating of NSS themes 2008 to 2016 


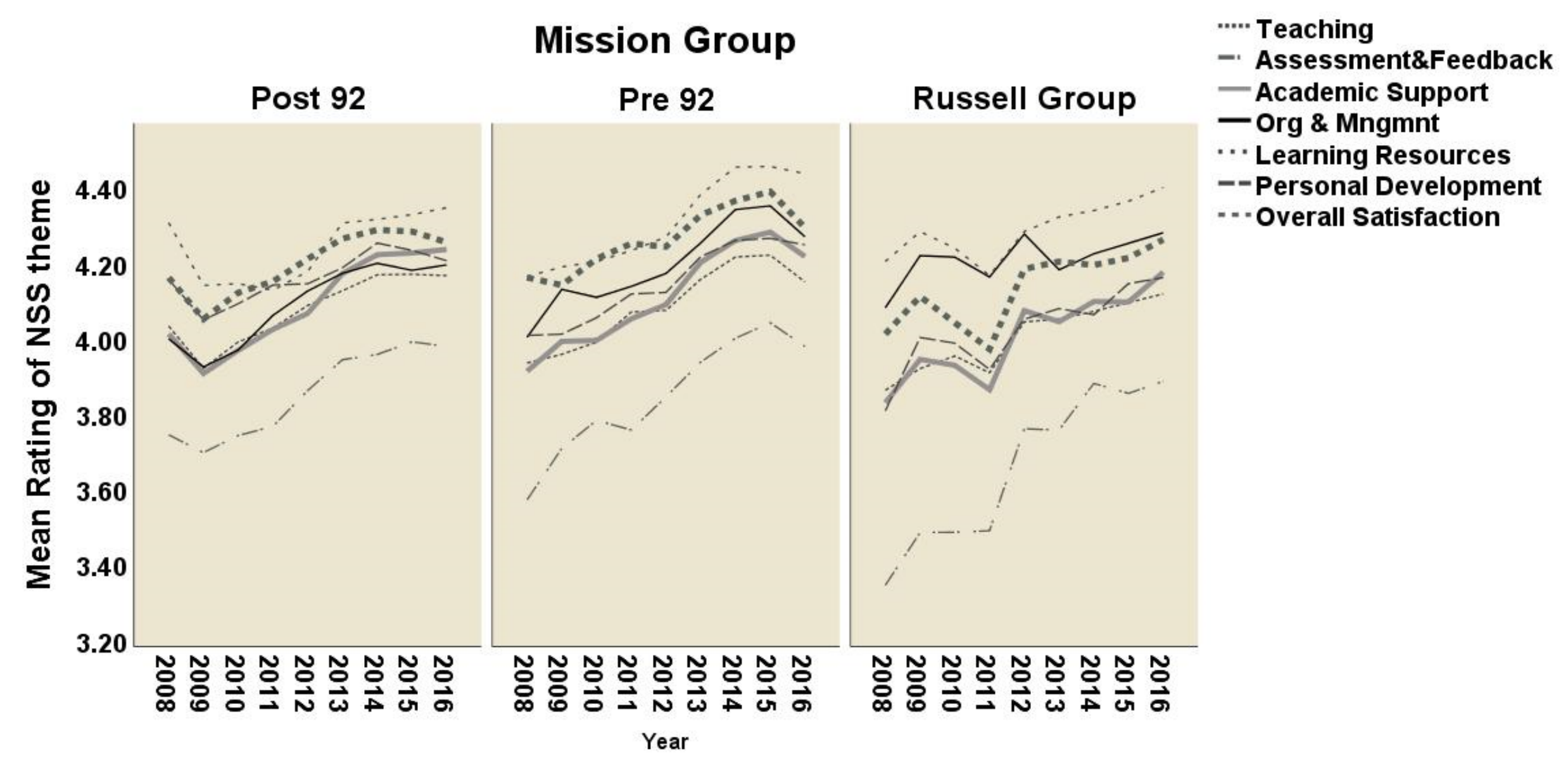

Figure 3: Rating of NSS themes by University Mission Group 2008 to 2016. 


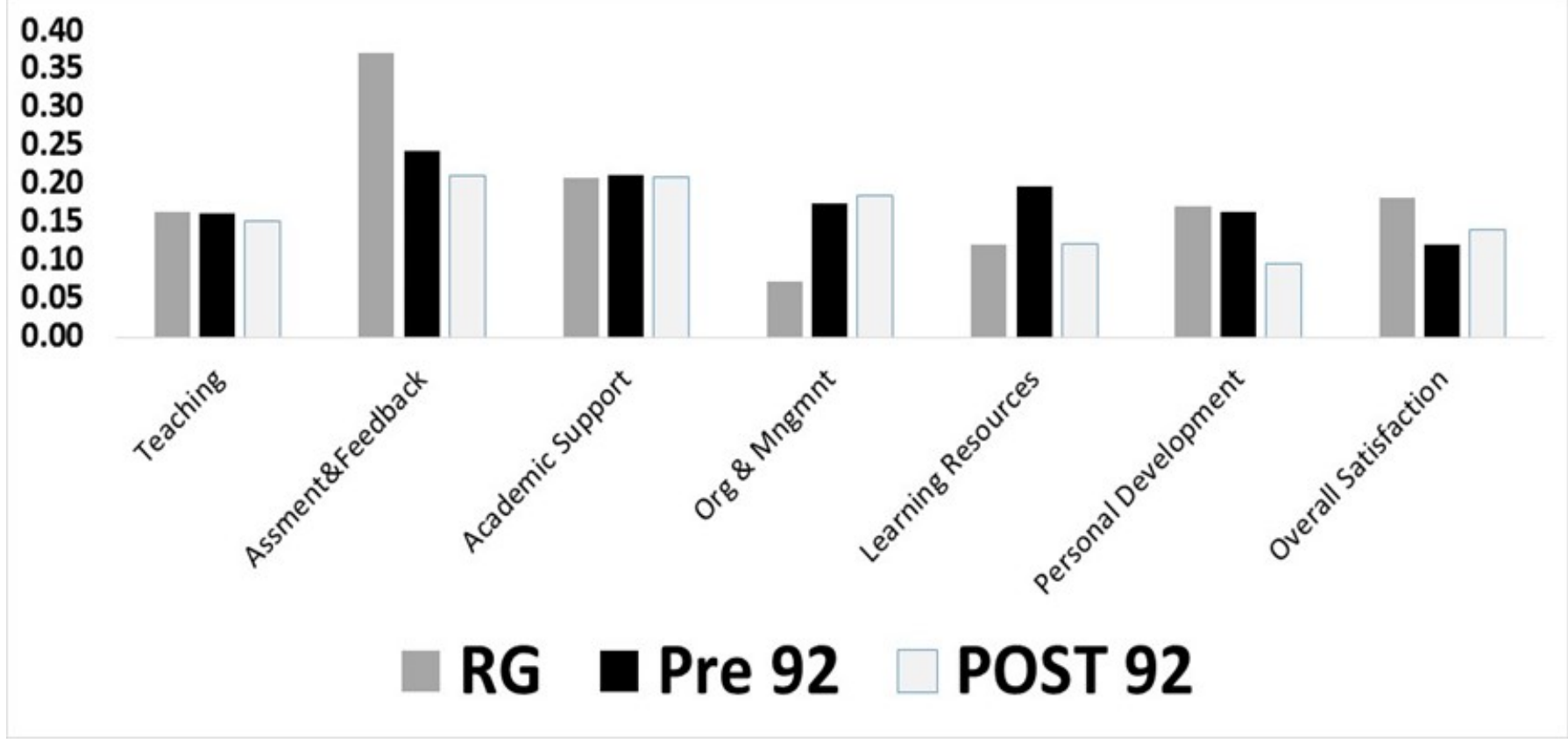

Figure 4: Largest improvement in ratings, of NSS themes, by university mission group. 
Tables:

Table 1: Spearman Correlation Results of NSS items (Q1 to 21) with Q22 (overall satisfaction) over the two time periods

\begin{tabular}{|c|c|c|c|c|c|c|c|}
\hline \multicolumn{4}{|c|}{ Time Period 1} & \multicolumn{4}{|c|}{ Time Period 2} \\
\hline \multicolumn{4}{|c|}{ 2008-2011 } & \multicolumn{4}{|c|}{ 2012-2016 } \\
\hline $\begin{array}{c}\text { NSS } \\
\text { Theme }\end{array}$ & $\begin{array}{c}\text { NSS } \\
\text { Questions }\end{array}$ & $\begin{array}{l}\text { Correlation } \\
\text { Coefficient }\end{array}$ & Sig. & $\begin{array}{c}\text { NSS } \\
\text { Theme }\end{array}$ & $\begin{array}{c}\text { NSS } \\
\text { Questions }\end{array}$ & $\begin{array}{l}\text { Correlation } \\
\text { Coefficient }\end{array}$ & Sig. \\
\hline $\begin{array}{c}\text { Organisation } \\
\& \\
\text { Management }\end{array}$ & Q15 & 0.597 & 0.000 & Teaching & Q1 & 0.833 & 0.000 \\
\hline $\begin{array}{c}\text { Personal } \\
\text { Development }\end{array}$ & Q19 & 0.577 & 0.000 & $\begin{array}{l}\text { Academic } \\
\text { Support }\end{array}$ & Q10 & 0.831 & 0.000 \\
\hline $\begin{array}{c}\text { Personal } \\
\text { Development }\end{array}$ & Q21 & 0.568 & 0.000 & $\begin{array}{c}\text { Organisation } \\
\& \\
\text { Management }\end{array} \mid$ & Q15 & 0.811 & 0.000 \\
\hline Teaching & Q1 & 0.563 & 0.000 & Teaching & Q3 & 0.801 & 0.000 \\
\hline $\begin{array}{c}\text { Academic } \\
\text { Support }\end{array}$ & Q10 & 0.562 & 0.000 & Teaching & Q4 & 0.797 & 0.000 \\
\hline Teaching & Q2 & 0.549 & 0.000 & Teaching & Q2 & 0.789 & 0.000 \\
\hline $\begin{array}{c}\text { Academic } \\
\text { Support }\end{array}$ & Q12 & 0.538 & 0.000 & $\begin{array}{c}\text { Academic } \\
\text { Support }\end{array}$ & Q12 & 0.781 & 0.000 \\
\hline Teaching & Q4 & 0.526 & 0.000 & $\begin{array}{c}\text { Personal } \\
\text { Development }\end{array}$ & Q19 & 0.754 & 0.000 \\
\hline $\begin{array}{c}\text { Personal } \\
\text { Development }\end{array}$ & Q20 & 0.516 & 0.000 & \begin{tabular}{|c|} 
Personal \\
Development
\end{tabular} & Q21 & 0.750 & 0.000 \\
\hline
\end{tabular}


Table 2: Comparison of ordinal Regression

\begin{tabular}{|c|c|c|c|c|c|c|}
\hline & \multicolumn{2}{|c|}{ Time Period 1} & \multicolumn{2}{|c|}{ Time Period 2} \\
\hline & & & \multicolumn{2}{|c|}{2008 to 2011} & \multicolumn{2}{|c|}{2012 to 2016} \\
\hline & & & Estimate & Sig. & Estimate & Sig. \\
\hline \multirow[t]{4}{*}{ Threshold } & & \begin{tabular}{|l|} 
[newQ22 = \\
$1.00]$
\end{tabular} & 9.978 & 0.000 & 85.856 & 0.000 \\
\hline & & \begin{tabular}{|l|} 
newQ22 = \\
$2.00]$
\end{tabular} & 12.593 & 0.000 & 90.536 & 0.000 \\
\hline & & \begin{tabular}{|l|} 
newQ22 = \\
$3.00]$
\end{tabular} & 14.993 & 0.000 & 93.078 & 0.000 \\
\hline & & \begin{tabular}{|l|} 
[newQ22 = \\
$4.00]$ \\
\end{tabular} & 19.907 & 0.000 & 100.422 & 0.000 \\
\hline & \multirow[t]{4}{*}{ Teaching } & Q1 & 0.599 & 0.000 & 2.793 & 0.217 \\
\hline & & $\mathrm{Q} 2$ & 0.325 & 0.000 & -2.764 & 0.127 \\
\hline & & Q3 & 0.081 & 0.075 & 1.129 & 0.481 \\
\hline & & Q4 & 0.375 & 0.000 & 3.647 & 0.017 \\
\hline & \multirow[t]{5}{*}{$\begin{array}{l}\text { Assessment } \\
\text { \& Feedback }\end{array}$} & Q5 & 0.081 & 0.028 & -1.521 & 0.192 \\
\hline & & Q6 & 0.133 & 0.001 & 1.832 & 0.116 \\
\hline & & Q7 & 0.077 & 0.045 & 0.926 & 0.331 \\
\hline & & Q8 & 0.040 & 0.341 & 0.248 & 0.829 \\
\hline & & Q9 & 0.066 & 0.106 & -0.199 & 0.871 \\
\hline & \multirow[t]{3}{*}{$\begin{array}{l}\text { Academic } \\
\text { Support }\end{array}$} & Q10 & 0.327 & 0.000 & 4.594 & 0.010 \\
\hline & & Q11 & 0.187 & 0.000 & 0.811 & 0.539 \\
\hline & & Q12 & 0.118 & 0.005 & 0.198 & 0.905 \\
\hline & \multirow[t]{3}{*}{$\begin{array}{c}\text { Organisation } \\
\& \\
\text { Management }\end{array}$} & Q13 & 0.117 & 0.001 & -2.264 & 0.011 \\
\hline & & Q14 & 0.039 & 0.324 & -2.070 & 0.075 \\
\hline & & Q15 & 0.767 & 0.000 & 9.112 & 0.000 \\
\hline & \multirow[t]{3}{*}{$\begin{array}{l}\text { Learning } \\
\text { Resources }\end{array}$} & Q16 & 0.124 & 0.001 & -0.306 & 0.763 \\
\hline & & Q17 & 0.054 & 0.224 & 2.244 & 0.151 \\
\hline & & Q18 & 0.018 & 0.683 & -1.865 & 0.207 \\
\hline & \multirow[t]{3}{*}{$\begin{array}{c}\text { Personal } \\
\text { Development }\end{array}$} & Q19 & 0.474 & 0.000 & 5.001 & 0.012 \\
\hline & & Q20 & 0.079 & 0.135 & -0.112 & 0.950 \\
\hline & & Q21 & 0.528 & 0.000 & 2.572 & 0.190 \\
\hline
\end{tabular}

